\title{
SOSIO DEMOGRAFI PEREMPUAN PEMANFAATAN DETEKSI DINI KANKER SERVIK METODE IVA DI BUKITTINGGI
}

\author{
Mesalina, Rosa ${ }^{* 1)}$, Sulung, Neila ${ }^{2)}$, Nurhayati ${ }^{3)}$ \\ 1, Politeknik Kesehatan Kemenkes Padang Prodi D3 Kebidanan Bukittinggi \\ ${ }^{2,3}$ Program Studi S2 Kesehatan Masyarakat STIKes Fort De Kock Bukittinggi \\ Jl. Soekarno-Hatta No.11 Manggis Ganting, Manidangin Koto Selayan Bukittinggi Indonesia, 26117 \\ email: mesalina580@gmail.com, neilasulung_64@yahoo.com,
}

Submitted: 14-02-2019, Reviewer: 18-02-2019, Accepted: 25-06-2019

\begin{abstract}
In 2013, the prevalence of cervical cancer in West Sumatra was 0.9 per 1,000 populations, higher than the prevalence of Indonesia. The low participation of women to be involved in the early detection is one of the cause's cervical cancers. The purpose of this study is to identify factors sociodemographic with the utilization of VIA in the Bukittinggi City 2018. This study is a mixed method research with a sequential cross sectional phenomenology approach, held from August to November 2018. The population was women of childbearing age and samples were taken by cluster sampling 191 respondents. Data collection used questionnaires and through focus group discussions (FGD) on two women's groups. Data analysis used Chi-Square test and theme analysis. $70.2 \%$ of respondents not utilize VIA test. There are no variables that have a significant relationship with the utilization of VIA; age 10.112 , OR 0.524 CI 95\% 0.247 - 1,111, education (0.415), work (1,000, OR 0.964 CI 95\% 0.516 - 1,799) parity (1,000, OR 0.976 CI 95\% 0.525 - 1,814) and income $(0.635$, OR 0.856 CI 95\% 0.459-1.598). Many reasons women not utilize VIA test. Therefore it is necessary to understand the influence of other factors in the early detection of VIA.
\end{abstract}

Keywords: VIA, socio-demography

Tahun 2013, prevalensi kanker serviks di Sumatera Barat adalah 0.9 per 1.000 penduduk, lebih tinggi dari prevalensi Indonesia (0.8/1.000 penduduk). Rendahnya partisipasi perempuan melakukan deteksi dini kanker serviks merupakan salah satu penyebab tingginya kejadian kanker serviks. Tujuan penelitian untuk mengetahui hubungan sosio demografi dengan pemanfaatan deteksi dini IVA di Kota Bukittinggi tahun 2018. Penelitian ini adalah penelitian mixed method dengan pendekatan cross sectional fenomenologi sekuensial dilaksanakan bulan Agustus sampai November 2018. Populasi penelitian adalah wanita usia subur dan sampel diambil secara cluster sampling sebanyak 191 responden. Pengumpulan data menggunakan kuesioner dan melalui diskusi kelompok terarah (DKT) pada dua kelompok perempuan yaitu suku Jawa dan Minang. Analisis data menggunakan uji Chi-Square dan analisis tema. Hasil penelitian menunjukkan $70.2 \%$ responden tidak melakukan pemeriksaan IVA. Hasil uji statistik menemukan bahwa tidak ada hubungan signifikan antara pemanfaatan deteksi dini kanker serviks IVA dengan umur ( 0.112 , OR 0.524 CI 95\% $0.247-1.111)$, pendidikan $(0.415)$, pekerjaan $(1.000$,OR 0.964 CI 95\% 0.516 - 1.79), paritas (1.000, OR 0.976 CI 95\% $0.525-1.814)$ dan penghasilan (0.635, OR 0.856 CI 95\% 0.459-1.598). Banyak alasan perempuan tidak melakukan pemeriksaan IVA. Oleh karena itu perlu memahami pengaruh faktor lain dalam perilaku deteksi dini kanker serviks IVA ini.

Kata kunci: IVA, sosio demografi 


\section{PENDAHULUAN}

Indonesia mengalami kondisi double burden penyakit yaitu mengalami permasalahan penyakit menular dan penyakit tidak menular sekaligus. Selama dua dekade terakhir telah terjadi transisi epidemiologis yaitu kecenderungan meningkatnya prevalensi penyakit menular yang diikuti pula dengan peningkatan prevalensi penyakit tidak menular, salah satunya kanker serviks. Kondisi ini memerlukan upaya strategis dalam pengendalian penyakit. Maka dari itu diperlukan deteksi dini yang berkualitas sebagai tindakan preventif. (Kementerian Kesehatan RI, 2015).

Kanker serviks adalah penyakit kanker perempuan terbanyak yang menyebabkan kematian. Diperkirakan 530.000 kasus baru kanker serviks dan 275.000 meninggal di seluruh dunia dan hal yang mengejutkan adalah $90 \%$ terjadi di negara berkembang. Data World Health Organization (WHO) tahun 2010, diketahui terdapat 493.243 jiwa per tahun penderita kanker serviks baru di dunia dengan angka kematian karena kanker ini sebanyak 273.505 jiwa per tahun. (Gustiana, Yulia Irvani, \& Sofiana, Nurchayati, 2014). Salah satu penyebab dari kanker serviks adalah infeksi human pappiloma virus (hPV) yang menyebabkan perubahan sel epitel serviks. (Anwar, 2014).

Di Indonesia, estimasi insidens kanker serviks 17 per 100.000 perempuan. (Kementerian Kesehatan RI, 2013). Prevalensi penyakit kanker serviks adalah prevalensi tertinggi di Indonesia yaitu 0.8 dengan jumlah angka kematian akibat kanker serviks di RS Kanker Dharmais menunjukkan peningkatan setiap tahunnya yaitu 35 kasus (2011), 42 kasus (2012) dan 65 kasus (2013). (Pusdatin Kemenkes RI, 2016). Di Sumatera Barat, prevalensi dan estimasi jumlah penderita penyakit kanker serviks provinsi tahun 2013 adalah 0.9 melalui diagnosa dokter dan 2.285 kasus menurut estimasi jumlah absolut. Angka ini lebih tinggi dari prevalensi nasional yaitu 0.8 atau sekitar 98.692 penduduk. (Pusdatin Kemenkes RI, 2016).

Kanker serviks dapat dicegah baik secara primer seperti mencegah faktor resiko terjadinya kanker serviks dan vaksinasi maupun secara sekunder dengan melakukan skrining untuk mendeteksi perubahan pada serviks secara dini sebelum berkembang menjadi kanker sehingga dapat disembuhkan dengan segera. Salah satu cara deteksi dini kanker serviks yang dapat dilakukan dengan metode Inspeksi Visual Asam Asetat. (IVA). (Akinyemiju, Jasmine, \& Paula, 2015)

Skrining IVA efektif untuk menurunkan morbiditas dan mortalitas kanker serviks, memiliki beberapa keuntungan yaitu pemeriksaannya sederhana, mudah, cepat, biaya sangat murah dan hasil dapat diketahui langsung serta dapat segera di terapi. Bila dibandingkan dengan pemeriksaan Pap Smear's maka kepekaan IVA dalam mendeteksi kelainan pada serviks lebih tinggi dari Pap Smear's yaitu 75\%. (Irianto, 2015). Penelitian di India, menyatakan bahwa sensitivitas IVA $89 \%$ dibandingkan Pap Smear's 52\%. (Bhattacharvya, 2015)

Namun demikian, cakupan pemeriksaan IVA belum maksimal. Di Indonesia, angka penapisan kanker seviks ini hanya $5 \%$. (Irianto, 2015). Pemeriksaan IVA, menurut Eko Fajri (2017) berdasarkan teleconfrence antara Dinas Kesehatan Provinsi Sumatera Barat dengan Kementerian Kesehatan cakupan pemeriksaan IVA adalah $34.5 \%$. Hal inilah yang menyebabkan $76.6 \%$ pasien datang dengan kaker serviks telah memasuki stadium lanjut bahkan sudah menyebar ke organ-organ lain sehingga menyebabkan biaya pengobatan menjadi lebih mahal dan angka kematian semakin tinggi (Juanda \& Kesuma, 2015). Cakupan deteksi dini dengan IVA minimal $80 \%$ selama lima tahun akan menurunkan insidens kanker serviks secara signifikan. Indikator 
pencapaian sasaran menurut Renstra tahun 2015-2019 perempuan usia 30-50 tahun yang dideteksi dini kanker serviks $50 \%$. (Kementerian Kesehatan RI, 2015).

Di Bukittinggi, menurut laporan Pencegahan dan Pengendalian Penyakit (P2P) tahun 2017, dari 13.602 WUS dengan sasaran pemeriksaan IVA (usia 30-50 tahun) 2.723 WUS yang telah memeriksakan diri adalah 591 WUS (21.7\%), 12 diantaranya IVA positif dan 4 dicurigai kanker. Data per wilayah kerja Puskesmas adalah Puskesmas Guguk Panjang (7.9\%), Puskesmas Rasimah Ahmad (34.1\%), Puskesmas Tigo Baleh (7.9\%), Puskesmas Gulai Bancah (8.4\%) dan Puskesmas Mandiangin (22\%). Data ini menunjukkan bahwa masih rendahnya kesadaran wanita untuk memeriksakan diri. (Dinas Kesehatan Kota Bukittinggi, 2017)

Pemeriksaan IVA merupakan perilaku kesehatan. Menurut Lawrence Green (1980) dalam Achmadi (2014), perilaku kesehatan ditentukan oleh tiga faktor utama yaitu faktor predisposisi, faktor pemungkin, dan faktor penguat. Faktor predisposisi meliputi tingkat pendidikan dan tingkat sosial ekonomi. (Achmadi, 2014). Menurut Newman dan Anderson (1973) dalam Notoatmodjo (2010), model demografi mempengaruhi penggunaan pelayanan kesehatan termasuk pemanfaatan deteksi dini kanker serviks.

Banyak faktor yang berhubungan dengan pemanfaatan deteksi dini kanker serviks metode IVA, diantaranya adalah faktor sosial demografi seperti umur, pendidikan, pekerjaan dan paritas. Hasil penelitian menyebutkan bahwa tingkat pengetahuan, umur, pekerjaan dan kepercayaan yang positif memiliki hubungan yang signifikan dengan pemeriksaan deteksi dini kanker serviks. (Mupepi, Carolin, \& Timothy, 2011). Penelitian di Nigeria, faktor yang berhubungan dengan praktik skrining kanker serviks adalah status pernikahan, tingkat pendidikan, status pekerjaan dan paritas.
(Mbachu, Cyill, \& Uche, 2017). Hasil penelitian lainnya mendapatkan bahwa $87.8 \%$ responden yang melakukan skrining kanker serviks dengan status bekerja (Mbachu et al., 2017). Pada penelitian di Lampung, didapatkan ada hubungan yang signifikan status ibu bekerja dalam melaksanakan deteksi dini kanker serviks. (Febriani, 2016). Hasil penelitian di Sulawesi Tengah, wanita yang memiliki kategori pendidikan tinggi lebih banyak melakukan deteksi dini kanker serviks yaitu 65\% (Rasyid \& Afni, 2017).

Penelitian tentang pemanfaatan IVA ini telah banyak dilakukan, namun belum ada penelitian yang dilakukan berbasis komunitas dengan beberapa cluster puskesmas. Hal ini memungkinkan untuk dilakukan analisis karakteristik sosio demografi perempuan dalam pemanfaatan deteksi dini kanker serviks IVA berbasis wilayah.

Selain itu, pemberian informasi tentang IVA telah sangat luas dilaksanakan dengan berbagai metode dan media. Hasil wawancara dengan Kasie. P2P Dinas Kesehatan Kota Bukittinggi menyebutkan bahwa hampi $50 \%$ masyarakat di Bukittinggi telah terinformasi tentang program IVA. Namun demikian capaian pemeriksaan IVA tetap belum maksimal pada penghujung pencapain tujuan renstra Kementerian Kesehatan jangka menengah 2015-2019.

Tujuan penelitian ini adalah untuk mengetahui faktor sosiodemografi yang berhubungan dengan pemanfaatan deteksi dini kanker serviks metode IVA.

\section{METODE PENELITIAN}

Jenis penelitian ini adalah penelitian Penelitian ini adalah penelitian mixed method dengan pendekatan cross sectional fenomenologi sekuensial yaitu menggabungkan unsur pendekatan penelitian kualitatif dan kuantitatif. Strategi 
yang digunakan dengan strategi eksplanatori sekuensial dimana pengumpulan dan analisis data kuantitatif pada tahap pertama yang diikuti dengan pengumpulan dan analisis data kualitatif pada tahap kedua, yang dibangun berdasarkan hasil awal kuantitatif. (Creswell, 2010). Penelitian dilaksanakan di 5 wilayah kerja Puskesmas di Bukittinggi pada bulan Agustus sampai Oktober 2018. Populasi dalam penelitian ini adalah wanita usia subur usia 30-50 tahun (sasaran program IVA), menikah dan tidak melakukan deteksi dini kanker serviks dengan metode lain dalam 12 bulan terakhir berjumlah 13.602. Jumlah sampel 191 responden dan 2 kelompok Diskusi Kelompok Terarah. Data diambil dengan teknik cluster sampling dan informan penelitian ditentukan dengan purposive sampling. Pengumpulan data menggunakan angket (checklist) tentang variabel yang diisi responden dengan memberi tanda centang $(\sqrt{ })$ pada kolom yang disediakan dan wawancara terpimpin yang memuat pertanyaan dan jawaban Analisis univariat dengan distribusi frekuensi dan analisis bivariat menggunakan uji statistik ChiSquare dengan confident interval 95\% dan melihat Odds Ratio (OR) atau kekuatan hubungan antara variabel independen dan variabel dependen. Anlisa kalitatif dilakukan dengan analisis domain, taksonomi dan analisis komponensia serta triangulasi data.

\section{HASIL DAN PEMBAHASAN}

\section{Pemanfaatan Deteksi Dini Kanker Serviks Metode IVA}

Tabel 1 menunjukkan bahwa dari 191 responden, $134 \quad(70.2 \%)$ WUS tidak memanfaatkan deteksi dini kanker serviks metode IVA tahun 2018. Pemeriksaan IVA merupakan salah satu alternatif metode skrining selain Pap Smear. Pada tahun 1985
WHO merekomendasikan suatu pendekatan alternatif bagi negara yang sedang berkembang dengan konsep down staging terhadap kanker servik. Pemeriksaan IVA memiliki keuntungan dalam mendeteksi lesi pra kanker. IVA merupakan tes yang sederhana, terjangkau dan memiliki sensitifitas yang tinggi dibanding tes Pap's Smear.

Data penelitian ini menunjukkan rendahnya capaian pemeriksaan IVA di Kota Bukittinggi. Target Kementerian Kesehatan dalam RPJMN tahun 2019 adalah $50 \%$.

Hasil penelitian ini sejalan dengan banyak hasil penelitian lainnya seperti penelitian di Zimbabwe bahwa 90.1\% tidak melakukan pemeriksaan deteksi dini kanker serviks (Mupepi et al, 2011). Demikian pula dengan penelitian di Afrika Selatan, 74.2\% perempuan tidak melakukan pemeriksaan deteksi dini kanker serviks (Akinyemiju et al, 2015), penelitian di Nigeria Tengah yaitu 92\% (Idowu et al, 2016), penelitian di Uganda 95.2\% (Ndejjo et al, 2016) dan penelitian di Ethiopia $89.3 \%$ (Gebreegziabher et al, 2016).

Rendahnya capaian pemeriksaan IVA ini dipengaruhi oleh berbagai faktor. Faktorfaktor yang mempengaruhi pemanfaatan IVA adalah pengetahuan, sikap, motivasi, persepsi, tingkat ekonomi, aksesibilitas. (Sidabutar et al, 2017). Alasan tidak melakukan pemeriksaan sangat bervariasi. Banyak penelitian yang mengungkapkan alasan responden tidak melakukan pemeriksaan adalah tidak adanya keluhan/gejala yang dirasakan, merasa penyakit tidak serius, rendahnya kesadaran untuk skrining, adanya rasa malu, takut dengan rasa sakit pada saat pemeriksaan, takut dengan hasil pemeriksaan, kurangnya dukungan suami. 


\section{Analisa Univariat}

Tabel 1 Distribusi Pemanfaatan Deteksi Dini Kanker Serviks Metode IVA di Bukittinggi Tahun 2018

\begin{tabular}{cccc}
\hline Variabel & Kategori & F $(\mathbf{N}=\mathbf{1 9 1})$ & \% \\
\hline Pemanfaatan IVA & - Tidak & 134 & 70.2 \\
& - Ya & 57 & 29.8 \\
\hline
\end{tabular}

Tabel 2 Distribusi Sosio Demografi Wanita Usia Subur di Bukittinggi Tahun 2018

\begin{tabular}{llcc}
\hline \multicolumn{1}{c}{ Variabel } & \multicolumn{1}{c}{ Kategori } & F $(\mathbf{N}=\mathbf{1 9 1})$ & \% \\
\hline Umur & - Risiko rendah $(<35$ tahun $)$ & 53 & 27.7 \\
& - Risiko tinggi $(\geq 35$ tahun $)$ & 138 & 72.3 \\
\hline Pendidikan & - Tinggi & 52 & 27.2 \\
& - Menengah & 100 & 52.4 \\
& - Rendah & 39 & 20.4 \\
\hline Pekerjaan & - Bekerja & 85 & 44.5 \\
& - Tidak bekerja & 106 & 55.5 \\
\hline Paritas & - Risiko rendah $(<3)$ & 93 & 48.7 \\
& - Risiko tinggi $(\geq 3)$ & 98 & 51.3 \\
\hline Penghasilan & - Baik $(\geq$ Rp. $2.100 .000,-)$ & 109 & 57.1 \\
& - Kurang baik $(<($ Rp. $2.100 .000,-)$ & 82 & 42.9 \\
\hline
\end{tabular}

\section{Analisis Bivariat}

Tabel 3 Uji Statistik Hubungan Sosio Demografi dengan Pemanfaatan Deteksi Dini Kanker Serviks Metode Inspeksi Visual Asam Asetat (IVA) di Kota Bukittinggi Tahun 2018

\begin{tabular}{|c|c|c|c|c|c|c|c|c|}
\hline \multirow{3}{*}{ Variabel Independen } & \multicolumn{4}{|c|}{ Pemanfaatan IVA } & \multirow{2}{*}{\multicolumn{2}{|c|}{$\begin{array}{c}\text { Total } \\
(\mathrm{N}=191)\end{array}$}} & \multirow{3}{*}{$\begin{array}{c}p \\
\text { value }\end{array}$} & \multirow{3}{*}{$O R$} \\
\hline & \multicolumn{2}{|c|}{ Tidak } & \multicolumn{2}{|c|}{ Ya } & & & & \\
\hline & $\mathbf{n}$ & $\%$ & $\mathbf{n}$ & $\%$ & $\mathbf{n}$ & $\%$ & & \\
\hline \multicolumn{9}{|l|}{ Umur } \\
\hline - Berisiko Tinggi & 92 & 66.7 & 46 & 33.3 & 138 & 100 & 0.112 & 0.524 \\
\hline - Berisiko Rendah & 42 & 79.2 & 11 & 20.8 & 53 & 100 & & $(0.247-1.111)$ \\
\hline \multicolumn{9}{|l|}{ Tingkat Pendidikan } \\
\hline - Rendah & 24 & 61.5 & 15 & 38.5 & 39 & 100 & 0.415 & - \\
\hline - Menengah & 72 & 72.0 & 28 & 28.0 & 100 & 100 & & \\
\hline - Tinggi & 38 & 73.1 & 14 & 26.9 & 52 & 100 & & \\
\hline \multicolumn{9}{|l|}{ Status Pekerjaan } \\
\hline - Tidak Bekerja & 74 & 69.8 & 32 & 30.2 & 106 & 100 & 1.000 & 0.964 \\
\hline - Bekerja & 60 & 70.6 & 25 & 29.4 & 85 & 100 & & $(0.516-1.799)$ \\
\hline \multicolumn{9}{|l|}{ Paritas } \\
\hline - Berisiko Tinggi & 65 & 69.9 & 28 & 30.1 & 93 & 100 & 1.000 & 0.976 \\
\hline - Berisiko Rendah & 69 & 70.4 & 29 & 29.6 & 98 & 100 & & $(0.525-1.814)$ \\
\hline \multicolumn{9}{|l|}{ Penghasilan } \\
\hline - Baik & 56 & 68.3 & 26 & 31.7 & 82 & 100 & 0.635 & 0.856 \\
\hline - Kurang baik & 78 & 71.6 & 31 & 28.4 & 109 & 100 & & $(0.459-1.598)$ \\
\hline
\end{tabular}




\section{Sosio Demografi}

Tabel 2 menunjukkan bahwa dari hasil penelitian didapatkan sosio demografi responden yaitu sebagian besar responden berumur risiko tinggi (72.3\%), sebagian responden dengan pendidikan menengah $(52.4 \%)$, sebagian responden tidak bekerja $(55.5 \%)$, sebagian responden dengan paritas risiko tinggi $(51.3 \%)$ dan sebagian responden berpenghasilan kurang baik $(42.9 \%)$.

\section{Umur}

Sebagian besar responden berumur risiko tinggi (72.3\%). Kelompok umur pada penelitian ini adalah 30-49 tahun, rata-rata umur responden adalah 39.1 tahun. Umur responden dibagi kedalam dua kelompok yaitu kelompok berisiko tinggi ( $\geq 35$ tahun) dan kelompok berisiko rendah ( $<35$ tahun). Pengelompokkan umur ini dimaksudkan untuk mengetahui kelompok umur mana yang paling memanfaatkan deteksi dini kanker serviks metode IVA.

Umur individu terhitung saat lahir sampai berulang tahun. Semakin cukup umur, tingkat kematangan dan kekuatan seseorang lebih matang dalam berpikir dan bekerja (Hurlock 1998). Umur adalah variabel yang selalu menjadi perhatian karena ada hubungan antara angka morbiditas dan mortalitas dengan umur. (Notoatmodjo, 2003). Usia ibu dalam kurun waktu reproduksi sehat adalah 20-35 tahun.

Hasil penelitian ini sejalan dengan penelitian di Nigeria Tenggara yaitu $93.6 \%$ responden dengan kategori umur berisiko tinggi (Mbachu et al, 2017), penelitian di Lampung yaitu $64.6 \%$ responden berumur risiko tinggi (Febriani, 2016). Demikian pula penelitian di Sukoharjo yaitu $76.7 \%$ (Saputri, 2016).

Hasil uji statistik (tabel 3) mendapatkan tidak ada hubungan anatara umur dengan pemanfaatan deteksi dini kanker serviks IVA. Sejalan dengan penelitian penelitian
Liu (2017) di China, penelitian di Puskesmas Singgani (Rasyid \& Afni, 2017) dan penelitian di Padang, (Fauza, Aprianti, \& Azrimaidaliza, 2019).

Semakin dewasa individu maka ia akan melakukan adaptasi perilaku terhadap lingkungannnya sehingga mau mengikuti perilaku kesehatan termasuk dalam mengikuti deteksi dini kanker serviks. (Febriani, 2016). Namun demikian, umur tidak dapat dijadikan tolok ukur bagi seseorang untuk melakukan pemeriksaan. Faktor lain seperti ketidaktahuan tentang pentingnya pemeriksaan, tidak ada keluhan yang dirasakan, alasan dan hambatan yang dirasakan seseorang dalam pemanfaatan deteksi dini kanker serviks dapat berpengaruh terhadap seseorang dalam pengambilan keputusan untuk memeriksakan diri.

\section{Pendidikan}

Sebagian responden dengan pendidikan menengah/sederajat SMA (52.4\%). Menurut UU Nomor 20 tahun 2003 tentang Sistem Pendidikan Nasional, membagi tiga tingkatan pendidikan yaitu tingkat pendidikan tinggi jika menamatkan diploma dan jenjang diatasnya, tingkat pendidikan menengah jika menamatkan SMA sederajat dan tingkat pendidikan rendah jika menamatkan SD/SMP sederajat.

Hasil penelitian ini sejalan dengan penelitian di India bahwa $60.9 \%$ responden dengan tingkat pendidikan menengah (Basu et al, 2006), penelitian di Jakarta $67 \%$ (Afiyanti, 2014) dan penelitian di Bogor, $52 \%$ responden berpendidikan menengah (Sulistiowati \& Sirait, 2014).

Analisa bivariat (tabel 3), tidak ada hubungan antara pendidikan dengan pemanfaatan deteksi dini kanker serviks IVA. Sejalan dengan penelitian ini yaitu penelitian di Pekanbaru (Gustiana et al, 2014), penelitian di Uganda (Ndejjo et al, 2016), penelitian di Afrika Selatan, 
(Gebreegziabher et al, 2016), penelitian di Yogyakarta (Tunggal \& Utami, 2016)

Pendidikan merupakan faktor penting yang mendorong seseorang untuk lebih peduli dan termotivasi untuk meningkatkan derajat kesehatan diri dan keluarganya. Pendidikan menjadikan seseorang memiliki pengetahuan yang luas dan pola pikirnya terbangun dengan baik, sehingga kesadaran untuk berperilaku positif termasuk dalam hal kesehatan semakin meningkat. (Ningrum \& Fajarsari, 2013).

Pendidikan adalah salah satu faktor yang mempengaruhi aspek pengetahuan. Pendidikan mempengaruhi proses belajar, makin tinggi pendidikan seseorang makin mudah orang tersebut untuk menerima informasi. (Wawan \& Dewi, 2010). Tingkat pendidikan seseorang dapat mempengaruhi tingkat pengetahuan seseorang. Semakin tinggi pendidikan seseorang maka semakin tinggi pemahaman seseorang terhadap informasi yang diterima yang berkontribusi pada tingginya pengetahuan seseorang (Parapat, Henry, \& Lintang, 2016).

Namun tidak dengan hasil penelitian ini, sebagian besar responden tidak melakukan pemeriksaan IVA baik pada kelompok pendidikan tinggi $(73.1 \%)$, pendidikan menengah $(72 \%)$ dan kelompok pendidikan rendah $(61.5 \%)$. Artinya pendidikan tidak dapat mempengaruhi responden untuk periksa IVA atau tidak. Bahkan lebih besar proporsi responden dengan tingkat pendidikan yang tinggi yang tidak melakukan pemeriksaan IVA.

Tinggi rendahnya tingkat pendidikan tidak berhubungan dengan tindakan deteksi dini kanker serviks karena dalam pengambilan keputusan untuk melakukan deteksi dini kanker serviks, pendidikan bukan satu-satunya faktor yang menentukan. Faktor-faktor lain yang berkaitan adalah adanya kepercayaan yang irasional, hambatan budaya dan faktor akses pelayanan kesehatan.

\section{Pekerjaan}

Sebagian responden tidak bekerja (55.5\%). Menurut Ananta (1993) yang dikutip oleh Yuliwati (2012), statistik pekerjaan mengelompokkan pekerjaan menjadi dua kelompok yaitu sektor formal dan sektor informal. Sektor formal adalah pekerjaan bergaji baik harian atau bulanan seperti pekerjaan dalam perusahaan industri, kantor pemerintahan dan perusahaan besar lainnya, memiliki struktur pekerjaan yang jelas, terorganisir dan ditandai dengan gaji yang tetap. Sektor informal mencakup istilah umum "usaha sendiri", kesempatan kerja kurang terorganisir, biasanya ditandai dengan gaji yang tidak tetap.(Yuliwati, 2012). Jenis pekerjaan dapat dibagi menjadi 1) Pedagang, 2) Buruh/tani, 3) PNS, 4) TNI/Polri, 5) Pensiunan, 6) Wiraswasta dan 7) ibu rumah tangga. (Notoatmodjo, 2003).

Hasil penelitian ini sejalan dengan penelitian yang di Manglore, India yaitu $59 \%$ responden tidak bekerja (Kumar \& Tanya, 2014).

Hasil uji statistik (tabel 3) mendapatkan tidak ada hubungan yang signifikan antara status pekerjaan dengan pemanfaatan deteksi dini kanker serviks metode IVA. Hasil penelitian ini sesuai dengan hasil penelitian di Bangladesh, (Rakibul, Robin, Baki, Mohammad, \& Susan, 2015), penelitian di Uganda, (Ndejjo et al., 2016), penelitian di Puskesmas Prembun, (Yuliwati, 2012), penelitian di Yogyakarta, (Tunggal \& Utami, 2016).

Pekerjaan adalah kebutuhan yang harus dilakukan terutama untuk menunjang kehidupannya dan kehidupan keluarga. Bekerja umumnya merupakan kegiatan yang menyita waktu serta dapat memberikan pengalaman maupun pengetahuan baik secara langsung maupun tidak langsung. Lingkungan pekerjaan dapat membentuk suatu pengetahuan karena adanya saling menukar informasi antara teman-teman di lingkungan kerja (Wawan \& Dewi, 2010). 
Hasil penelitian ini menyebutkan baik ibu yang bekerja maupun tidak bekerja sebagian besar tidak melakukan pemeriksaan IVA. Hal ini dapat dipengaruhi oleh banyak hal seperti adanya keterpaparan infomasi dan pengaruh teman yang tidak memeriksakan diri dengan IVA sehingga perempuan tidak melakukan pemeriksaan IVA. Selain itu, status tidak bekerja mempengaruhi kepada tingkat penghasilan sehingga perempuan banyak bergantung secara ekonomi dengan suami. Hal ini membatasi ibu untuk melakukan pemeriksaan karena adanya biaya transportasi yang harus disiapkan karena tidak semua fasilitas kesehatan dekat dan mudah dijangkau oleh sasaran.

\section{Paritas Responden}

Sebagian responden dengan kelompok paritas berisiko tinggi (51.3\%). Paritas/para adalah jumlah kehamilan yang diakhiri dengan kelahiran janin yang memenuhi syarat untuk melangsungkan kehidupan (28 minggu atau 1000 gram) (Varney, 2001). Penggolongan paritas bagi ibu berdasarkan jumlahnya menurut WHO, yaitu 1) primigravida adalah wanita hamil untuk pertama kali, 2) multigravida dalah wanita yang pernah hamil beberapa kali, dimana kehamilan tersebut tidak lebih dari 5 kali dan 3) grande multigravida adalah wanita yang pernah hamil lebih dari 5 kali. Paritas yang tidak berisiko adalah 1-3 sedangkan yang berisiko adalah $>3$.

Penelitian di India menyebutkan determinan yang menyebabkan kanker serviks adalah kebiasaan seksual, merokok, defisiensi nutrisi, penggunaan kontrasepsi hormonal dan paritas yang tinggi. (Sreedevi, Resma, \& Avani, 2015). Semakin tinggi paritas maka semakin besar potensi untuk terjadinya kanker serviks.

Sejalan dengan hasil penelitian ini adalah penelitian di Sukoharjo yaitu $53.4 \%$ responden dengan paritas risiko tinggi (Saputri, 2016). Demikian pula dengan penelitian di Bangladesh $63.8 \%$ (Rakibul et al., 2015) dan penelitian di India yaitu $67.5 \%$ responden dengan status paritas berisiko tinggi (Kumar \& Tanya, 2014).

Hasil uji statistik (tabel 3) mendapatkan tidak ada hubungan yang signifikan antara paritas dengan pemanfaatan deteksi dini kanker serviks metode IVA. Hasil penelitian ini sesuai dengan hasil penelitian (Ndejjo et al., 2016) dan penelitian (Gebreegziabher et al., 2016), penelitian (Mwaka et al., 2015).

Kejadian kanker serviks dapat meningkat seiring dengan bertambahnya jumlah anak yang dilahirkan. Dengan kata lain multiparitas juga meningkatkan risiko terjadinya kanker servik. (Andrews, 2009). Sebagian besar responden yang tidak melakukan pemeriksaan IVA terdapat pada kelompok paritas berisiko tinggi $(69.9 \% \%)$ dan kelompok paritas berisiko rendah (70.4\%). Artinya status paritas tidak dapat mempengaruhi responden untuk periksa IVA atau tidak.

Sebagian besar responden yang tidak melakukan pemeriksaan IVA pada kelompok paritas berisiko tinggi dan rendah dapat disebabkan beberapa faktor yaitu rendahnya kesadaran dan kerentanan perempuan tentang pentingnya upaya deteksi dini kanker servik. Perempuan dengan paritas risiko rendah tidak melakukan pemeriksaan karena merasa tidak ada risiko terjadinya kanker serviks dan umur masih realtif muda.

\section{Penghasilan keluarga}

Hampir sebagian responden dengan penghasilan yang kurang baik (42.9\%). Pendapatan keluarga adalah jumlah penghasilan riil dari seluruh anggota keluarga yang digunakan untuk memenuhi kebutuhan bersama maupun perseorangan dalam rumah tangga. (Suparyanto, 2014). Penghasilan merupakan salah satu hal yang mempengaruhi status sosial ekonomi keluarga. Tidak hanya menyangkut daya 
beli, keadaan sosial ekonomi juga mempengaruhi perilaku termasuk perilaku kesehatan.

Hasil penelitian sejalan dengan penelitian di Uganda yaitu $30.9 \%$ responden berpenghasilan kurang baik (Ndejjo et al, 2016), penelitian di Lampung yaitu $35.4 \%$ responden berpenghasilan kurang baik (Febriani, 2016).

Uji statistik Chi Square (tabel 3) menunjukkan bahwa tidak ada hubungan yang signifikan antara penghasilan dengan pemanfaatan deteksi dini kanker serviks metode IVA. Hasil penelitian sejalan dengan dengan penelitian di Kenya bagian Barat bahwa tidak ada hubungan antara penghasilan keluarga dengan pemanfaatan deteksi dini kanker serviks. (Omenge et al., 2016). Demikian pula dengan penelitian di Uganda dengan nilai $\mathrm{p}=0,567$ (Ndejjo et al., 2016) dan hasil penelitian di Riau dengan nilai $\mathrm{p}=0.561$ (Gustiana et al., 2014).

Kejadian kanker serviks erat kaitannya dengan status nutrisi wanita. Pola konsumsi yang buruk seperti kurangnya makan buah dan sayur dapat menyebabkan tubuh kekurangan (defisiensi) asam folat, vitamin $\mathrm{C}$, E, beta karotin/retinol yang dihubungkan dengan peningkatan risiko kanker serviks. (Rasjidi, 2007). Upaya menyediakan makanan yang bergizi ini berhubungan erat dengan status ekonomi yang dimiliki oleh keluarga terkait dengan daya beli keluarga.

Status ekonomi dalam bentuk penghasilan keluarga ini merupakan faktor penting yang mendorong motivasi seseorang untuk berperilaku hidup sehat karena tidak adanya kendala biaya yang dirasakan, bahkan biaya tersebut sudah dialokasikan untuk kebutuhan kesehatan. (Ningrum \& Fajarsari, 2013). Tingkat sosial ekonomi merupakan faktor predisposisi yang menyebabkan seseorang melakukan sesuatu atau berperilaku. (Achmadi, 2014)
Rendahnya penghasilan berkaitan erat pula dengan rendahnya status sosial ekonomi. Aspek ini berhubungan dengan rendahnya partisipasi dalam pemeriksaan deteksi dini kanker yang berdampak rendahnya perilaku deteksi dini secara rutin, mengurangi akses ke fasilitas pelayanan kesehatan karena aspek finansial (Chang, 2017). Perempuan dengan memiliki kemandirian finansial $6.61 \%$ akan lebih berminat melakukan pemeriksaan skrining IVA (Mupepi et al., 2011)

Menurut peneliti, hampir sebagian responden dengan penghasilan yang kurang baik disebabkan oleh sebagian responden juga dengan status tidak bekerja. Tidak memiliki pekerjaan menjadikan responden (keluarga) tidak memiliki penghasilan yang lebih selain penghasilan suami sebagai kepala keluarga. Penghasilan keluarga yang kurang baik ini dipengaruhi pula oleh sebagian besar responden dengan tingkat pendidikan menengah yang artinya memiliki keterbatasan keahlian dibandingkan dengan responden dengan pendidikan yang tinggi.

\section{Alasan tidak melakukan pemeriksaan IVA}

Dari hasil Diskusi Kelompok Terarah (focus group discussion) didapatkan alasan responden tidak melakukan pemeriksaan IVA yaitu ketidaksesuaian nilai-nilai dengan program IVA, budaya malu dan tabu dengan prosedur pemeriksaan, takut dengan prosedur dan hasil pemeriksaan, kepercayaan yang tidak mendukung dan tidak adanya dukungan suami.

\section{SIMPULAN}

Sebagian besar responden tidak memnafaatkan pemeriksaan deteksi dini kanker serviks metide IVA (70.2\%). Sosio demografi responden, $72.3 \%$ responden dengan kelompok umur berisiko tinggi, $52.4 \%$ responden dengan tingkat pendidikan menengah, $55.5 \%$ responden tidak bekerja, $51.3 \%$ responden dengan kelompok paritas 
berisiko tinggi dan $42.9 \%$ responden berpenghasilan kurang baik.

Hasil uji statistik Chi-Square, tidak ada variabel yang memiliki hubungan signifikan dengan pemanfaatan deteksi dini kanker serviks metode IVA yaitu umur (0.112), pendidikan (0.415), pekerjaan (1.000), paritas (1.000) dan penghasilan (0.635).

Secara teori, Anderson dan Newman (1973) dalam Notoatmodjo (2014) menyebutkan bahwa faktor sosio demografi berhubungan dengan pemanfaatan atau penggunaan pelayanan kesehatan termasuk deteksi dini kanker serviks metode IVA, namun tidak demikian dengan hasil penelitian ini. Karakter sosio demografi tidak lagi menjadi satu-satunya tolok ukur dalam melihat keterkaitan responden dengan penggunaan pelayanan kesehatan. Banyak faktor lain yang mempengaruhi pemanfaatan deteksi dini kanker serviks IVA baik faktor internal maupun faktor eksternal dari individu tersebut.

Alasan responden tidak melakukan pemeriksaan adalah hambatan psikologis yang dirasakan responden. Oleh karena itu, diperlukan kajian lebih dalam untuk mengetahui faktor yang berpengaruh dengan pemanfaatan deteksi dini kanker serviks metode IVA.

\section{UCAPAN TERIMAKASIH}

Dalam penelitian ini, penulis mengucapkan terimakasih kepada semua pihak yang telah membantu penyelesaian penelitian ini terutama dosen di STIKes Fort De Kock Bukittinggi, Kepala Dinas Kesehatan Kota Bukittinggi, Kepala Puskesmas tempat pelaksanaan penelitian, teman-teman Poltekkes Kemenkes Padang Kampus Kebidanan Bukittinggi, kelompok WUS yang menjadi informan serta keluarga tersayang dan semua pihak yang tak dapat disebutkan semuanya. Semoga Allah SWT membalas semua kebaikan yang dicurahkan dengan pahala yang setimpal.

\section{DAFTAR PUSTAKA}

Achmadi, U. F. (2014). Kesehatan Masyarakat Teori dan Aplikasi. Jakarta: PT. RajaGrafindo Persada.

Afiyanti, Y. (2014). Factors Affecting Behaviors of Cervical Cancer Screening Using VIA (Visual Inspection with Acetic Acid) Method on Women in Srengseng Sawah Jakarta Indonesia. UI HealthMed, 1, 1-4.

Akinyemiju, T. F, Jasmine, M. D, \& Paula, L. P. (2015). Health Care Access Dimensions and Cervical Cancer Screening in South Africa: Analysis of the World Health Survey. BioMed Central Public Health, (15:382), 1-8. https://doi.org/10.1186/ s12889-015-1686-5

Anwar, M. (2014). Ilmu Kandungan. (M. Anwar, A. Baziad, \& P. Prabowo, Eds.) (Edisi Keti). Jakarta: PT Bina Pustaka Sarwono Prawiirohardjo.

Basu, P, Mousumi, G, Kankan, C, Srabani, M, Pradip, D, Chounhury, D, \& Ranajit, M. (2006). Cervical Screening by Visual Inspection with Acetic Acid (VIA) is Well Accepted by Women - Results from a Community-based Study in Rural India. Asian Pacific Journal of Cancer Prevention, 7(October), 604-608.

Bhattacharvya, A. K, Jyan Dip, N., \& Harajyoti, Deka. (2015). Comparative Study Between Pap Smear and visual Inspection With Acetic Acid (VIA) in Screening of CIN and Early Cervical Cancer Background: Aim: Discussion: Summary: Conclusion: Journal of Mid Life Health, 6(2), 53-58. https://doi.org/10.4103/0976-7800.158942

Dinas Kesehatan Kota Bukittinggi. Laporan Pencegahan dan Pengendalian Penyakit Rekapitulasi Pemeriksaan IVA (2017).

Fauza, M., Aprianti, \& Azrimaidaliza. (2019). Faktor yang Berhubungan dengan Deteksi Dini Kanker Serviks Metode IVA di Puskesmas Kota Padang. Promosi Kesehatan, 14(1), 68-80.

Febriani, C. A. (2016). Faktor-faktor yang Berhubungan dengan deteksi Dini Kanker Leher Rahim di Kecamatan Gisting Kabupaten Tanggamus Lampung. Jurnal Kesehatan, VII Nomor, 228-237.

Gebreegziabher, M., Nigus Gebremedhin, A., \& 
Semarya, B. (2016). Factors Affecting the Practices of Cervical Cancer Screening among Female Nurses at Public Health Institutions in Mekelle Town, Northern Ethiopia, 2014: A Cross-Sectional Study. Journal of Cancer Research, 2016, 7 pages. https://doi.org/10.1155/2016/4743075

Gustiana, D, Yulia Irvani, D, \& Sofiana, Nurchayati. (2014). Faktor-faktor yang Berhubungan dengan Perilaku Pencegahan Kanker Serviks pada Wanita Usia Subur. JOM PSIK, Vol 1, Nom, 1-8.

Idowu, A, Samuel Anu, O, Aderonke Tolulope, F, \& Olumuyiwa Ayotunde, O. (2016). Determinants of Cervical Cancer Screening Uptake among Women in Ilorin, North Central Nigeria: A CommunityBased Study. Journal of Cancer Epidemiology, 2016, 8 pages. https://doi.org/10.1155/2016/6469240

Irianto, K. (2015). Kesehatan Reproduksi (Health Reproductive) Teori dan Praktikum. Bandung: CV. ALFABETA.

Juanda, D, \& Kesuma, H. (2015). Pemeriksaan Metode IVA (Inspeksi Visual Asam Asetat) untuk Pencegahan Kanker Serviks. Jurnal Kedokteran Dan Kesehatan, 2(2), 169-174.

Kementerian Kesehatan RI. (2015). Rencana Strategis Kemenkes RI Tahun 2015-2019. Jakarta: Kementerian Kesehatan RI.

Kementerian Kesehatan RI, L. (2013). Riset Kesehatan Dasar.

Kumar, H, \& Tanya, S. (2014). A Study on Knowledge and Screening for Cervical Cancer among in Manglore City. Annals of Medical dan Health Sciences Research, 4(5), 751-756. https://doi.org/10.4103/ 2141-9248.141547

Mbachu, C, Cyill, D, \& Uche, E. (2017). Effects of Peer Health Education on Perception and Practice of Screening For Cervical Cancer Among Urban Residential Women In South-East Nigeria : A Before And After Study. BioMed Central Wpmen's Health, 1-8. https://doi.org/ 10.1186/s12905-0170399-6

Mupepi, S, Carolin, M. S, \& Timothy, RJ. (2011). Knowledge, Attitudes, and Demographic Factors Influencing Cervical Cancer Screening Behavior of Zimbawean Women. Journal of Women's Health, 20, nomor, 943-952. https://doi.org /10.1089/jwh.2010.2062

Mwaka, A, Christopher, O, Edward, W, Georgios, L, Wabinga, H., \& Martin, R. (2015). Awareness of Cervical Cancer Risk Factors and Symptoms:Cross-Sectional Community Survey in Post Conflicy Northen Uganda. Health expectations published, 854-867. https://doi.org /10.1111/hex.12382

Ndejjo, R, Trasias, M, Angele, M, \& David, M. (2016). Uptake of Cervical Cancer Screening and Associated Factors among Women in Rural Uganda: A Cross Sectional Study. PLOS ONE, 1-13. https://doi.org/10.1371/journal.pone.01496 96

Ningrum, R. D, \& Fajarsari, D. (2013). Faktorfaktor yang Mempengaruhi Motivasi Ibu Mengikuti Deteksi Dini Kanker Serviks melalui IVA di Kab. Banyumas Tahun 2012. Bidan Prada: Jurnal Ilmiah Kebidanan, 4(1), 1-14.

Notoatmodjo, S. (2003). Ilmu Kesehatan Masyarakat. Jakarta: PT. Rineka Cipta.

Omenge, E, Juddy, W, Fredrick, CA, Naftali, B., Violet, N, Job, K., Thomas, I. (2016). Factors Associated with Uptake of Visual Inspection with Acetic Acid ( VIA ) for Cervical Cancer Screening in Western Kenya. PLOS ONE, 16, 1-12. https://doi.org/10.1371/journal.pone.01572 17

Parapat, F.T, Henry, S. \& Lintang, D. S. (2016). Faktor-faktor yang Berhubungan dengan Perilaku Deteksi Dini Kanker Leher Rahim Metode IVA di Puskesmas Candiroto Kab. Temanggung. Jurnal Kesehatan Masyarakat, $\quad 4, \quad 363-370$. https://doi.org/2356-3346

Pusdatin Kemenkes RI. (2016). Bulan Peduli Kanker Payudara (Oktober 20). Jakarta: Kementerian Kesehatan RI.

Rakibul, M.I, Robin, JB, Baki, B, Mohammad, H, \& Susan, D. (2015). Lack of Understanding of Cervical Cancer and Screening Is the Leading Barrier to Screening Uptake in Women at Midlife in Bangladesh: Population-Based CrossSectional Survey. The Oncologist Global Health and Cancer, 20, 1386-1392. 
Rasjidi, I. (2007). Panduan Penatalaksanaan Kanker Ginekologi Berdasarkan Evidence Based. Jakarta: Penerbit Buku Kedokteran - EGC.

Rasyid, N, \& Afni, N. (2017). Faktor-faktor yang Berhubungan dengan Perilaku wus (wanita usia subur) tentang Deteksi Dini Kanker Leher Rahim Metode Iva (Inspeksi Visual Asam Asetat) di Puskesmas singgani. Promotif, 7(1), 63-75.

Saputri, M. Hubungan Pengetahuan tentang Test Inspeksi Visual Asam Asetat (IVA) dengan Keikutsertaan Wanita dalam Melakukan Pemeriksaan di Desa Godegan Mojolaban Sukoharjo, 3-12 (2016). Surakarta.

Sidabutar, S, Santi, M., \& Chatarina, UW. (2017). Analysis of Factors Affecting Women of Childbearing Age to Screen Using Visual Inspection with Acetic Acid. Osong Public Health Res Perspect, 8(1), 61-64. https://doi.org/10.24171 2017.8.1.08

Sreedevi, A, Resma, J, \& Avani, D. (2015). Epidemiology of Cervical Cancer with
Special Focus On India. International journal of Women's Health, 7, 405-414. https://doi.org/10.2147/IJWH.550001

Sugiyono. (2016). Metode Penelitian Kuantitatif, Kualitatif dan $R \& D$. Bandung: CV. ALFABETA.

Sulistiowati, E, \& Sirait, AM. (2014). Pengetahuan tentang Faktor Risiko, Perilaku Dan Deteksi Dini Kanker Serviks Dengan Inspeksi Visual Asam Asetat (Iva) Pada Wanita Di Kecamatan Bogor Tengah, Kota Bogor. Buletin Penelitian Kesehatan, 42(3), 193-202.

Tunggal, N, \& Utami, S. (2016). Deteksi Dini Kanker Serviks Pada Ibu Rumah Tangga Di Pedesaan. Samodra Ilmu, 62, 133-141.

Wawan, A, \& Dewi. (2010). Teori dan Pengukuran Pengetahuan, Sikap, dan Perilaku Manusia. Yogyakarta: Nuha Medika.

Yuliwati. Faktor-faktor yang Berhubungan dengan Perilaku WUS dalam Deteksi Dini Kanker Leher Rahim Metode IVA di Wilayah Puskesmas Prembun Kabupaten Kebumen tahun 2012 (2012). 